\title{
POTENTIAL OF OZONE WATER TO REDUCE THE SEVERITY OF ORAL MUCOSITIS IN PATIENTS POST HEAD AND NECK RADIOTHERAPY
}

\author{
Annisa Gustiasti Arumsadu *, Niluh Ringga Woroprobosari**, Rina Kartika Sari*** , Rochman Mujayanto ${ }^{\star \star \star *}$ \\ *Program Pendidikan Dokter Gigi Fakultas Kedokteran Gigi Universitas Islam Sultan Agung \\ **Departemen RadiologI Kedokteran Gigi dan Forensik Universitas Islam Sultan Agung \\ ${ }^{* * * D}$ Departemen Penyakit Mulut Fakultas Kedokteran Gigi Universitas Islam Sultan Agung \\ **** Departemen Penyakit Mulut Fakultas Kedokteran Gigi Universitas Islam Sultan Agung \\ Correspondence: $\underline{\text { niluh.ringga@unissula.ac.id }}$
}

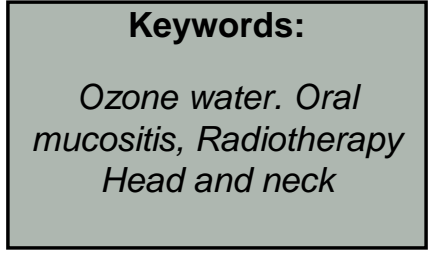

\begin{abstract}
Background: Cancer is the second leading cause of death in the world after heart disease. One type of cancer, namely head and neck cancer, can be treated with head and neck radiotherapy. Continuous radiotherapy will cause an increase in oxidative stress and free radicals and damage to the oral mucosa, one of which is oral mucositis. Giving ozone water can help reduce the degree of oral mucositis in patients. Ozone water itself has several beneficial effects such as antioxidant, anti-inflammatory, and antimicrobial.

The purpose of this study was to determine the potential of ozone water in reducing the severity of oral mucositis in patients after head and neck radiotherapy.

Method: The Article searches were conducted through an electronic database, namely PubMed, and based on keywords. Articles were selected based on inclusion criteria and obtained eight articles.

Result: Gargling treatment using ozone water in a ratio of 2:3 for 1 minute with 4 repetitions for 2 weeks showed a significant reduction in pain. Ozone used in gas or liquid form for more than 5 minutes has the potential to cause side effects on the duration of inflammation and for gas can cause infection in the respiratory tract.

Conclusion: The conclusion of this review is that the administration of ozone water with a concentration of 2-4 ppm for approximately 5 minutes has the potential to cure oral mucositis due to head and neck radiotherapy
\end{abstract}

\section{PENDAHULUAN}

Radioterapi kepala dan leher adalah salah satu terapi pengobatan pada pasien yang mengalami kanker pada daerah kepala dan leher. Kanker kepala dan leher meliputi nasofaring, orofaring, laring, dan hipolaring. Hal tersebut banyak ditemukan di usia 40-50 tahun ${ }^{1}$. Radioterapi yang diberikan selama pengobatan kanker kepala dan leher dapat memicu terjadinya kerusakan sel dan menyebabkan terjadinya perubahan pada rongga mulut. Efek sitotoksik dari radioterapi mengakibatkan stress oksidatif, peningkatan produksi reactive oxygen species (ROS), dan meningkatkan radikal bebas. Radikal bebas yang berlebihan akan menyebabkan kerusakan DNA pada sel epitel di mukosa oral ${ }^{2}$. Dampak yang ditimbulkan seperti mukositis, xerostomia dan osteoradionecrosis ${ }^{3}$.

Mukositis oral merupakan salah satu efek samping paling sering terjadi pada pasien kanker yang menjalani terapi radiasi. Elting et.al. (2008) melaporkan risiko mukositis identik terjadi pada 126 
pasien dengan rongga mulut atau tumor orofaring, serta 65 pasien dengan tumor laring atau hipofaring, yang keduanya melakukan tindakan radiography ${ }^{4}$. Hasil penelitian Fleckenstein et.al.(2011) menunjukkan bahwa keseluruhan pasien yang terdiri dari 14 pria dan 2 wanita yang hanya menerima tindakan $\mathrm{RT}, 13$ pria dan 2 wanita yang menerima RCT, secara keseluruhan mengalami mukositis. DSB (DNA Double-Strand Breaks) yang tidak diperbaiki dalam kurun waktu 24 jam memiliiki tingkat keparahan mukositis lebih tinggi dibandingkan pasien yang diberikan treatment perbaikan setelah paparan radiasi dalam kurun waktu 24 jam $^{5}$. Hasil penelitian tersebut didukung oleh De Lima et.al. (2012) yang menyebutkan bahwa pada keseluruhan objek penelitian yaitu pasien kanker kepala dan leher dengan usia 18-75 tahun dengan tindakan cemoradiography secara keseluruhan mengalami mukositis oral selama masa pengobatan. Mukositis yang diinduksi oleh radiasi dikenal dengan radiation induced oral mucositis $(R I O M)^{6}$. Sebuah studi mendapatkan prevalensi mencapai $40 \%$ dari seluruh pasien ${ }^{7}$. Studi lain yang dilakukan di Brazil, mendapatkan prevalensi mukositis oral yang diinduksi oleh radiasi yakni $41.9 \%$ dan lebih tinggi pada laki-laki $(78.2 \%)^{8}$.

RIOM dimulai dengan inflamasi akut pada mukosa oral, lidah, dan faring setelah pemberian radioterapi dan dapat berprogres mengancam nyawa bila menyebabkan keterbatasan asupan nutrisi yang berakibat penurunan berat badan. Hal ini menyebabkan terapi pada kanker menjadi terputus dan perlu penyesuaian dosis fraksinasi radiasi ${ }^{9}$. Studi menemukan bahwa terdapat derajat berkembangnya RIOM, dimulai dengan fase preulser yang ditandai dengan hiperemia dan eritema, kemudian diikuti fase epithelial dimana terdapat beberapa derajat deskuamasi dan kerusakan membrane basal dengan kehilangan barrier protektif, dan diikuti oleh fase postulseratif, tergantung dari keparahan toksisitas jaringan. Dapat terjadi infeksi sekunder dengan bakteri gram negative atau jamur. Fase terakhir yakni fase penyembuhan dan fibrosis 9 .

Tujuan dari penelitian ini ialah mengetahui potensi air ozon dalam menurunkan derajat keparahan mukositis oral pada pasien pasca radioterapi kepala dan leher.

\section{METODE}

Pencarian artikel dilakukan melalui database elektronik yaitu PubMed. Adapun berdasarkan keyword (Ozone Water AND Oral Mucositis AND Radiotherapy), (Ozone Water AND Head and Neck Cancer), (Ozone Therapy AND Mucositis, AND Radiotherapy Head and Neck), (Ozone Therapy AND Oral Mucositis) dan (Ozone AND Mucositis Cancer Adjuvant) yang digunakan diperoleh sebanyak 403.158 artikel yang selanjutnya discreening kembali menjadi 78.046 artikel berbahasa inggris yang terbit dalam 15 tahun terakhir. Jumlah artikel yang dapat diakses fulltext sebanyak 33.396 artikel yang kemudian disesuaikan dengan kriteria inklusi dan diperoleh 8 artikel sesuai dengan kriteria inklusi. 


\section{RESULT}

Tabel 1 Hasil Kajian (Literature Review)

Penulis dan Tahun Judul Metode Penelitian

Hasil

\begin{tabular}{llll}
\hline Tasdoven et al., & $\begin{array}{l}\text { Effects of ozone } \\
\text { oxidative preconditioning } \\
\text { (2019) }\end{array}$ & Pemberian perlakuan pada hewan & Kelompok yang \\
& Dibadiation-induced & Kelompok kontrol, kelompok perlakuan & ozon dan iradiasi memiliki \\
organ damage in rats & saline dan iradiasi, dan kelompok ozon & jaringan HPO lebih tinggi \\
& & dan iradiasi. Pemberian ozon dengan & dibanding perlakuan \\
& cara intraperitoneal dengan dosis 1,2 & saline.
\end{tabular}
$\mathrm{mg} / \mathrm{kg}$ sehari.

\begin{tabular}{|c|c|c|}
\hline Clavo et al., (2018) & $\begin{array}{l}\text { Ozone therapy as } \\
\text { adjuvant for cancer } \\
\text { treatment: Is further } \\
\text { research warranted? }\end{array}$ & $\begin{array}{l}\text { Pemberian ozon pada hewan yang } \\
\text { mengalami tumor melalui insuflasi rectal } \\
\text { selama } 12 \text { sesi.. }\end{array}$ \\
\hline Martinez., (2020) & $\begin{array}{l}\text { Evaluation of the effect } \\
\text { of ozone therapy with } \\
\text { ozonized water in oral } \\
\text { mucositis of pediatric } \\
\text { cancer patients }\end{array}$ & $\begin{array}{l}\text { Pemberian air ozon pada } 15 \text { orang } \\
\text { pasien mukositis oral usia 1-15 tahun. } \\
\text { Perlakuan yang diberikan kumur dengan } \\
\text { air suling yang diberi ozon dengan } \\
\text { generator selama } 5 \text { menit (ozonated } \\
\text { water). } \\
\text { Untuk usia 1-6 tahun diberikan } 10 \mathrm{ml} \text {, } \\
\text { usia } 7-15 \text { tahun diberikan } 150-200 \mathrm{ml} \\
\text { dengan cara berkumur dalam jangka } \\
\text { waktu } 5 \text { menit. Skala nyeri diukur } \\
\text { sebelum dan setelah pemberian } \\
\text { perlakuan. }\end{array}$ \\
\hline
\end{tabular}

Pada hewan hasilnya mengalami penurunan pada jumlah sel tumor.

\begin{tabular}{|c|c|c|c|}
\hline Bayer et al., (2017) & $\begin{array}{l}\text { Comparison of laser and } \\
\text { ozone treatments on } \\
\text { oral mucositisin an } \\
\text { experimental model }\end{array}$ & $\begin{array}{l}\text { Pemberian perlakuan pada } 24 \text { hewan } \\
\text { coba yang terbagi menjadi } 3 \text { kelompok. } \\
\text { Kelompok kontrol, kelompok laser, dan } \\
\text { kelompok ozon. } \\
\text { Pemberian ozon menggunakan } \\
\text { generator ozon dengan campuran } \\
\text { oksigen } 80 \% \text { selama } 120 \text { detik dalam } \\
\text { waktu } 5 \text { hari. }\end{array}$ & $\begin{array}{l}\text { Ozon dan laser memiliki } \\
\text { potensi dalam } \\
\text { penyembuhan untuk } \\
\text { mukositis. }\end{array}$ \\
\hline Yildirim et al., (2015) & $\begin{array}{l}\text { Mucositis Treatment } \\
\text { Using Ozonated Water }\end{array}$ & $\begin{array}{l}\text { Case report mengenai pemberian air } \\
\text { ozon sebagai obat kumur dan dilakukan } \\
\text { selama } 7 \text { hari pada pasien laki-laki usia } \\
7 \text { tahun. }\end{array}$ & $\begin{array}{l}\text { Pada hari pertama pasien } \\
\text { melaporkan nyeri } \\
\text { berkurang }\end{array}$ \\
\hline Hayashi et al., (2019) & $\begin{array}{l}\text { Effects of ozone nano- } \\
\text { bubble water on } \\
\text { mucositis induced by } \\
\text { cancerchemotherapy }\end{array}$ & $\begin{array}{l}\text { Pemberian perlakuan pada } 3 \text { kelompok } \\
\text { yaitu kelompok salin, Kelompok kontrol, } \\
\text { dan Kelompok ONBW (ozone nano } \\
\text { bubblewater). } \\
\text { ONBW menggunakan gelembung mikro } \\
\text { dengan diameter } 200 \mathrm{~nm} \text {. }\end{array}$ & $\begin{array}{l}\text { Penggunaan ONBW } \\
\text { (ozone nano } \\
\text { bubblewater) pasien } \\
\text { mengalami penurunan } \\
\text { rasa nyeri. }\end{array}$ \\
\hline $\begin{array}{l}\text { Harkema \& wagner., } \\
(2019)\end{array}$ & $\begin{array}{l}\text { Innate Lymphoid Cell- } \\
\text { Dependent Airway } \\
\text { Epithelial and } \\
\text { Inflammatory } \\
\text { Responses to Inhaled } \\
\text { Ozone: A New Paradigm } \\
\text { in Pathogenesis }\end{array}$ & $\begin{array}{l}\text { Literature review mengenai paparan } \\
\text { ozon pada hewan dengan dosis } 0.15 \\
\text { ppm selama } 6-90 \text { hari dengan waktu } \\
\text { paparan } 6 \text { jam/hari. }\end{array}$ & $\begin{array}{l}\text { Paparan ozon di secara } \\
\text { terus menerus akan } \\
\text { menyebabkan reaksi } \\
\text { asma dan pernapasan } \\
\text { dan lainnya. }\end{array}$ \\
\hline
\end{tabular}




\begin{tabular}{llll}
\hline Speen et al.,(2019) & Small Molecule & Literature review mengenai pemberian & Paparan ozon \\
& Antipsychotic & ozon pada sel epitel manusia yang telah & menyebabkan respon \\
& Aripiprazole Potentiates & dikultur yang kemudian diberi paparan & inflamasi pada sel HBE \\
& Ozone-Induced & ozon 0.4 ppm selama 4 jam di dalam & (Human Bronchial \\
& Inflammation in Airway & ruangan. & Ephitelial) \\
& Epithelium & & \\
\hline
\end{tabular}

\section{DISKUSI}

Radiasi memiliki efek samping tergantung dari usia, daerah penyinaran, luas lapangan penyinaran, organ yang berada di sekitar tumor, cara penyinaran dan juga alat yang digunakan untuk radiasi, serta jumlah dosis yang dipaparkan. Efek samping yang muncul bisa cepat lambat, bisa terjadi secara lokal ataupun umum, dan bisa terjadi dari ringan sampai berat. Terapi radiasi pada kepala dan leher dapat mengakibatkan berbagai macam efek samping seperti mukositis, gangguan pada kelenjar saliva, gangguan pada indera pengecap dan malnutrisi, gangguan gigi geligi, serta perubahan pada tulang ${ }^{18}$.

Terapi radiasi pada daerah leher dan kepala terbukti menjadi salah satu penyebab dari rusaknya struktur kelenjar saliva dengan berbagai derajat kerusakan. Sel mukosa mengalami aktivitas mitosis yang tinggi dan rentan terhadap efek berbahaya dari radioterapi. Paparan radiasi pada rongga mulut dan mukosa faring dapat menyebabkan perkembangan mukositis oral yang diinduksi oleh radiasi (radiation induced oral mucositis/RIOM). Terdapat lima fase pengembangan RIOM menurut Le et al. (2020) dengan penjelasan sebagai berikut ${ }^{19}$.

- Fase 1 (fase inisiasi): radiasi menciptakan kerusakan DNA untai ganda dalam sel, mengkatalisis kerusakan endotel

- Fase 2 (fase epitel): induksi NF-kB dan pelepasan sitokin pro-inflamasi yang dapat muncul sebagai eritema

- Fase 3 (pensinyalan seluler dan fase amplifikasi sinyal): pembawa pesan proinflamasi (misalnya TNF-\#) dilepaskan sehingga meningkatkan regulasi caspases dan ceramide synthase untuk kemudian mempromosikan apoptosis seluler.

- Fase 4 (ulserasi): efek aktivitas pro-inflamasi agregat dan mengembangkan kerusakan mukosa, menghasilkan pembentukan pseudomembran fibrin (nidus untuk mikroflora atau infeksi oportunistik)

- Fase 5 (penyembuhan): proliferasi epitel baru dan restorasi mikrobioma normal, biasanya 3 minggu setelah radioterapi atau, jika penyembuhan terganggu, dapat berkembang menjadi kerusakan luka, ulserasi, dan/atau nekrosis permanen

Volume saliva dilaporkan juga mengalami pengurangan akibat radiografi karena adanya kerusakan kelenjar. Jumlah dan keparahan kerusakan jaringan kelenjar saliva bergantung pada dosis dan jangka waktu penyinaran. Hubungan antara dosis penyinaran dan sekresi saliva dapat dilihat pada tabel 2 .

Tabel 1 Hubungan antara dosis penyinaran dan sekresi saliva (Yunus, 2008)

\begin{tabular}{cc}
\hline Dosis & Gejala \\
\hline$<\mathbf{1 0}$ Gray & $\begin{array}{c}\text { Reduksi tidak tetap sekresi } \\
\text { saliva }\end{array}$ \\
\hline $\mathbf{1 0 - 1 5}$ Gray & $\begin{array}{c}\text { Hiposialia yang jelas dapat } \\
\text { ditunjukkan }\end{array}$ \\
\hline $\mathbf{1 5 - 4 0}$ Gray & $\begin{array}{c}\text { Reduksi masih terus } \\
\text { berlangsung, reversible }\end{array}$ \\
\hline $\mathbf{4 0}$ Gray & $\begin{array}{c}\text { Perusakan irreversible } \\
\text { jaringan kelenjar (Hiposilis } \\
\text { irreversible) }\end{array}$ \\
\hline
\end{tabular}

Gejala penurunan produksi saliva dapat dilihat setelah beberapa minggu pertama 
radioterapi. Penurunan laju aliran saliva ini tergantung dari dosis yang diberikan, biasanya terjadi antara 0-60 Gy.. Mulut akan terasa kering (xerostomia) dan nyeri. Gambaran histologi pada jaringan yang mengalami inflamasi akan muncul setelah terapi radiasi, khususnya pada serous acini (kelenjar serous). Beberapa bulan setelah radioterapi dilakukan, inflamasi akan semakin parah dan glandula akan menjadi fibrosis, adiposis, kehilangan pembuluh darah, dan seiring dengan itu jaringan parenkim akan mengalami degenerasi. Hal tersebut akan menimbulkan xerostomia ${ }^{18}$.

Perubahan saliva ini akan mempengaruhi mikroflora rongga mulut dan gigi. Hal ini sering memicu terjadinya karies akibat dari radiasi. Setelah radiasi glandula saliva mayor, mikroflora akan berubah, dan perubahan tersebut dapat menyebabkan saliva lebih asam dan juga menyebabkan timbulnya plak. Pasien yang menjalani radioterapi menyebabkan jumlah Streptococcus mutans, Lactobasilus, dan Candida meningkat. Karena jumlah saliva yang sedikit, kental, dan asam maka akan mengakibatkan karies radiasi pada pasien. Kondisi mikroflora pada rongga mulut akan menginduksi terjadinya mukositis $^{18}$. Banyaknya GNB (Fusobacterium, Haemophilus, Tannerella, Porphyromonas dan Eikenella) pada mukosa bukal akan mempengaruhi kerentanan pasien untuk meningkatkan keparahan mukositis ${ }^{20}$.

Pasien yang melakukan treatment berkumur menggunakan air ozon dengan perbandingan 2:3 selama 1 menit dengan pengulangan sebanyak 4 kali selama 2 minggu menunjukkan pengurangan rasa nyeri yang signifikan. Total pengaplikasian sebanyak 8 kali. Pasien menerima terapi topikal kortikosteroid konvensional (betametason natrium fosfat $500 \mathrm{mg}$ tablet larut) setelah melakukan perawatan menggunakan air ozon ${ }^{25}$. Studi menyebutkan bahwa ozon dapat diaplikasikan pada gigi setiap dua hari dalam satu minggu secara oral rinse. Pengaplikasian ozon secara efektif mengurangi peradangan gingiva. Irigasi air ozon dalam bentuk gas dapat mengurangi efek inflamasi dalam pengobatan periodontitis ${ }^{21}$.

Mukositis Oral seringkali berkaitan dengan ulserasi pada jaringan mukosa rongga mulut pasien yang sedang menjalankan kemoterapi dan radioterapi. Radiasi ke daerah kepala dan leher dapat menyebabkan nilai mukositis di pasien hampir $98-100 \%$. Lapisan kortikal mukosa mulut ditutupi dengan stratifikasi epitel skuamosa, di bawahnya terletak jaringan ikat fibrosa yang mengandung sejumlah besar pembuluh kapiler. Penyembuhan luka di mukosa mulut mengikuti proses vasokonstriksi, pembentukan gumpalan darah, pembentukan fibrin, infiltrasi sel inflamasi, proliferasi sel, neovaskularisasi, dan regenerasi epitel $^{15}$.

Terapi ozon telah dipercaya dapat meningkatkan unit perfusi darah pada minggu pertama pasca operasi dan hasil ini juga konsisten dengan peningkatan penyembuhan luka yang disertai dengan peningkatan kualitas hidup. Ozon memiliki efek menguntungkan pada penyembuhan luka di jaringan keras dan lunak. Dosis kecil ozon dapat mengaktifkan mekanisme biokimia dan mengaktifkan kembali sistem antioksidan. Pemeriksaan histopatologi menunjukkan bahwa ozon mengurangi peradangan dan edema dan berguna dalam penyembuhan luka pada jaringan lunak dan keras ${ }^{13}$. Ketika oksigen aktif dihilangkan oleh superoksida dismutase (SOD), hidrogen peroksida (H2O2) diproduksi. $\mathrm{H} 2 \mathrm{O} 2$ terlibat dalam vasodilatasi sebagai faktor hiperpolarisasi yang diturunkan dari endotel (EDHF). Oleh karena itu, diperkirakan bahwa ozon memperluas pembuluh perifer melalui $\mathrm{H} 2 \mathrm{O} 2$ dan meningkat perfusi darah tepi. Hal ini menjadi sebuah keuntungan sendiri 
bagi pemberian ozon untuk menurunkan tingkat mukositis oral pada pasien radioterapi ${ }^{22}$.

Terapi ozon dapat menyebabkan stres oksidatif terkontrol yang mampu merangsang respons antioksidan adaptif di jaringan sehat. Beberapa studi klinis melaporkan adanya modulasi radikal bebas dan antioksidan menggunakan terapi ozon dengan cara menurunkan toksisitas yang terjadi akibat kemoterapi maupun radioterapi ${ }^{11}$. Pemberian ozon yang terkontrol dapat meminimkan kerusakan yang disebabkan oleh ROS (reactive oxygen species) dengan mempertahankan adaptasi stress sehingga dapat meningkatkan penyembuhan luka iskemik dan ulkus dengan meningkatkan ekspresi, sekresi serta aktivasi faktor pertumbuhan dari trombosit yang diaktifkan ${ }^{10}$. Ozon berpengaruh pada kasein kinase 2 (CK2) (pengatur lain dari aktivitas Nrf2 melalui fosforilasi) dan melibatkan modulasi (penghambatan) jalur NF-KB. Jalur ini mengaktifkan pelepasan sitokin proinflamasi seperti: TNF $\alpha$, INFY, IL1 $\beta$, IL6, IL8, serta gen pro-inflamasi seperti siklooksigenase-2 (COX2) dan sintase oksida nitrat yang diinduksi (iNOS). Dosis yang diberikan dalam terapi ozon dan respons hormetiknya memiliki peran penting untuk mengelola keseimbangan respons peradangan / pro-inflamasi keseimbangan. regulasi Nrf2 dan NF$\mathrm{KB}$ untuk mempertahankan homeostasis redoks dalam sel sehat ${ }^{11}$.

Berkaitan dengan factor mikrobiologi, mukositis disebabkan melalui dua hal yaitu banyaknya jumlah bakteri pada mulut karena tertutupi lendir dan permukaan yang mengalami ulserasi akibat radioterapi yang ditutupi dengan bahan nekrotik sebagai tempat berkembang biak bakteri. Kedua kondisi tersebut mengganggu penyerapan obat-obatan sehingga diperlukan terapi ozon untuk mengurangi derajat keparahan mukositis dengan mereduksi jumlah bakteri pada rongga mulut. Ozon dapat mengganggu integritas kapsul sel bakteri melalui oksidasi fosfolipid dan lipoprotein dengan cara berpenetrasi ke kapsul sel bakteri yang nantinya akan mempengaruhi secara langsung integritas cytoplasmic dan mengganggu beberapa tingkat kompleksitas metabolic, sehingga dapat membunuh bakteri secara langsung 15,23.

Ozon yang digunakan di dunia medis diproduksi dengan mengggunakan generator dengan campuran oksigen murni melalui gradien tegangan tinggi 5 hingga $13 \mathrm{mV}$. Produk akhir adalah campuran gas yang mengandung $95 \%$ oksigen dan 5\% ozon. Ozon merupakan gas yang sangat tidak stabil dengan waktu paruh 40 menit pada $20^{\circ} \mathrm{C}$ dan harus segera digunakan. Generator harus memiliki fotometer yang akurat dan menghitung konsentrasi ozon yang tepat dalam campuran. Apabila bercampur dengan udara, ozon dapat bereaksi menjadi gas beracun yang membahayakan tubuh manusia diantaranya mengakibatkan efek samping peradangan, epifora, rhinitis, batuk, sakit kepala, mual dan muntah. Ozon dosis tinggi juga dapat mengakibatkan komplikasi paru apabila masuk saluran pernafasan ${ }^{24}$.

Ozon yang dihirup akan bereaksi dengan lipid pada tubuh sehingga menghasilkan oksisterol reaktif dan elektrofilik yang mampu menyebabkan disfungsi seluler serta peradangan. Enzim yang mengatur langkah terakhir biosintesis kolesterol dan 7- dehydrocholesterol reductase (DHCR7) akan mengubah lipid menjadi 7-dehydrocholesterol (7-DHC) menjadi kolesterol. Penghambatan DHCR7 meningkatkan kadar 7-DHC yang jauh lebih rentan terhadap oksidasi sehingga dapat menginduksi peningkatan kadar kolesterol ${ }^{17}$. Ozon juga menginduksi sel limfoid (ILC2s) sehingga dapat menyebabkan alergi rinitis dan asma pada pasien ${ }^{16}$. Ozon dapat memicu komplikasi paru apabila tidak digunakan pada dosis yang tepat. Oksidasi protein, tiol, dan amina selama proses 
peroksidasi asam lemak tak jenuh ganda dapat menyebabkan kerusakan serius di dalam tubuh ${ }^{24}$

\section{KESIMPULAN}

Pemberian Air ozon dengan konsentrasi 24 ppm selama kurang lebih 5 menit berpotensi dalam penyembuhan mukositis oral akibat dari radioterapi kepala dan leher. treatment berkumur menggunakan air ozon dengan perbandingan 2:3 selama 1 menit dengan pengulangan sebanyak 4 kali selama 2 minggu menunjukkan pengurangan rasa nyeri yang signifikan Ozon yang digunakan dalam bentuk gas ataupun cair lebih dari 5 menit berpotensi menimbulkan efek samping pada lamanya inflamasi dan untuk gas efek sampingnya dapat menimbulkan infeksi pada saluran pernapasan.

\section{DAFTAR PUSTAKA}

1. Surjadi, N., \& Amtha, R. Radiotherapy Reduced Salivary Flow Rate and Might Induced C. albicans Infection.Journal of Dentistry Indonesia.2011; 19(1):1-

2. Marliyawati, D., Wiratno, \& Yusmawan, W. et al. Pengaruh Pemberian Polifenol Madu Terhadap Mukositis Oral Akibat Kemoradiasi Pada Penderita Kanker Kepala dan Leher. Media Medika Indonesiana. 2016;1(4): 67-74.

3. Supriatno, \& Subagyo, G. Perawatan Kandidiasis Pseudomembran Akut dan Mukositis Oral pada Penderita Kanker Nasofaring yang Menerima Kemoterapi dan Radioterapi.Majalah Kedokteran Gigi Indonesia.2011; 18(2):182-186.

4. Elting, L. S., Keefe, D. M., Sonis, S. T., Garden, A. S., Spijkervet, F. K. L., Barasch, A., ... \& Burden of Illness Head and Neck Writing Committee. Patient-reported measurements of oral mucositis in head and neck cancer patients treated with radiotherapy with or without chemotherapy: demonstration of increased frequency, severity, resistance to palliation, and impact on quality of life. Cancer. 2018; 113(10): 2704-2713.

5. Fleckenstein, J., Kühne, M., Seegmüller, K., Derschang, S., Melchior, P., Gräber, S., ... \& Rübe, C. The impact of individual in vivo repair of DNA double-strand breaks on oral mukositis in adjuvant radiotherapy of head-and-neck cancer. International Journal of Radiation Oncology* Biology* Physics. 2011;81(5): 14651472.

6. De Lima, A. G., Villar, R. C., de Castro Jr, G., Antequera, R., Gil, E., Rosalmeida, M. C., ... \& Snitcovsky, I. M. L. Oral mucositis prevention by low-level laser therapy in head-and-neck cancer patients undergoing concurrent chemoradiotherapy: a phase III randomized study. International Journal of Radiation Oncology* Biology* Physics.2012; 82(1): 270275.

7. Razmara, F., \& Khayamzadeh, M. An Investigation into the Prevalence and Treatment of Oral Mucositis After Cancer Treatment [Review Article]. International Journal of Cancer Management.2015;3(1): https://sites.kowsarpub.com/ijcm/articles/8840 5.html\#abstract

8. Pereira, I. F., Firmino, R. T., Meira, H. C., Vasconcelos, B. C. D. E., Noronha, V. R. A. D. S., \& Santos, V. R. Radiation-induced Oral Mucositis in Brazilian Patients: Prevalence and Associated Factors. In Vivo.2019; 33(2): 605609. https://doi.org/10.21873/invivo.11517

9. Maria, O. M., Eliopoulos, N., \& Muanza, T. Radiation-Induced Oral Mucositis. Frontiers in Oncology. 2017; https://doi.org/10.3389/fonc.2017.00089

10. Taşdöven, İ., Emre, A. U., Gültekin, F. A., Öner, M. Ö., Bakkal, B. H., Türkcü, Ü. Ö., Gün, B. D., \& Taşdöven, G. E. Effects of ozone preconditioning on recovery of rat colon anastomosis after preoperative radiotherapy. Advances in Clinical and Experimental Medicine. 2019; 28(12): 1683-1689. https://doi.org/10.17219/ACEM/110329

11. Clavo, B., Santana-Rodríguez, N., Llontop, P., Gutiérrez, D., Suárez, G., López, L., Rovira, G., Martínez-Sánchez, G., González, E., Jorge, I. J., Perera, C., Blanco, J., \& RodríguezEsparragón, F. Ozone therapy as adjuvant for cancer treatment: Is further research warranted? Evidence-Based Complementary and Alternative Medicine, 2018. https://doi.org/10.1155/2018/7931849

12. Martinez, L., Karina, P., Ventura, R. Evaluation of the effect of ozone therapy with ozonized water in oral mucositis of pediatric cancer patients. Journal of Dental Science, Oral and Maxillofacial Research.2020.

13. Bayer, S., Kazancioglu, H.O., Acar, A.H. et al. Comparison of laser and ozone treatments on oral mukositis in an experimental model. Lasers Med Sci.2017; 32, 673-67. https://doi.org/10.1007/s10103-017-2166-1

14. Yildirim, C., Martı, O., Atas, E., Ozdemir, A., \& Acar, O. International Journal of Advances in 
Mucositis Treatment Using Ozonated Water.2015;2(3): 161-163.

15. Hayashi, K., Onda, T., Honda, H., Ozawa, N., Ohata, H., Takano, N., \& Shibahara, T. Effects of ozone nano-bubble water on mucositis induced by cancer chemotherapy. Biochemistry and Biophysics Reports.2019; 20. https://doi.org/10.1016/j.bbrep.2019.100697

16. Harkema, J. R., \& Wagner, J. G. Innate Lymphoid Cell-Dependent Airway Epithelial and Inflammatory Responses to Inhaled Ozone: A New Paradigm in Pathogenesis. Toxicol Pathol.2019; 47(8): 993-1003. https://doi.org/10.1177/0192623319873872.In nate

17. Speen, A. M., Hoffman, J. R., Kim, H.-Y. H., Escobar, Y. N., Nipp, G. E., Rebuli, M. E., Porter,N. A., \&amp; Jaspers, I. Small Molecule Antipsychotic Aripiprazole Potentiates OzoneInduced Inflammation in Airway Epithelium. Chem Res Toxicol.2019; 32(10): 19972005.https://doi.org/10.1021/acs.chemrestox.9 b00149.Gene

18. Yunus, B. Efek samping terapi radiasi penderita kanker kepala dan leher pada kelenjar saliva. Journal of Dentomaxillofacial Science.2008; $7(1)$, https://doi.org/10.15562/jdmfs.v7i1.194

19. Le, R. T., Behzadi, F., Fiester, P., Patel, J., Dagan, R., \& Rao, D. Radiologic Findings of Radiation-Induced Oral Mucositis Background / introduction.2020; 1-13.

20. Vesty, A., Gear, K., Biswas, K., Mackenzie, B. W., Taylor, M. W., \& Douglas, R. G. Oral microbial influences on oral mucositis during radiotherapy treatment of head and neck cancer. Supportive Care in Cancer.2020; 28(6): 2683-2691. https://doi.org/10.1007/s00520019-05084-6

21. Talmaç, A. C., \& Çalişir, M. (2020). Efficacy of gaseous ozone in smoking and non-smoking gingivitis patients. Irish Journal of Medical Science (1971 -). doi:10.1007/s11845-02002271-x

22. Kuroda, K., Yamashita, M., Murahata, Y., Azuma, K., Osaki, T., Tsuka, T., Ito, N., Imagawa, T., \& Okamoto, Y. Use of ozonated water as a new therapeutic approach to solve current concerns around antitumor treatment. Experimenyal and Therapeutic Medicine.2018; 16 , https://doi.org/10.3892/etm.2018.6415

23. Mardiyono, Ramlan, D., Anwar, M. C., Pujiastuti, R. S. E., \& Rahayu, U. M. Modern combinations Dressing and Ozone Bagging Treatment. Journal of Applied Healath Management and Technology.2019; 1(1): 28-37.

24. Yen Y. C., Yang, C. Y., Ho, C. K., Yen, P. C., Cheng, Y. T., Mena, K. D., Lee, T. C., \& Chen,
P. S. Indoor ozone and particulate matter modify the association between airborne endotoxin and schoolchildren's lung function. Science of the Total Environment.2020; 705(100), 135810 . https://doi.org/10.1016/j.scitotenv.2019.135810

25. Veneri, F., Bardellini, E., Amadori, F. Efficacy of ozonized water for the treatment of erosive oral lichen planus: A randomized controlled study. Medicina Oral Patologia Oral y Cirugia Bucal.2020; 25(5). 